GRASAS Y ACEITES 67 (3)

July-September 2016, e143

ISSN-L: 0017-3495

doi: http://dx.doi.org/10.3989/gya.0993152

\title{
Virgin almond oil: Extraction methods and composition
}

\author{
J.M. Roncero ${ }^{\mathrm{a}}$, M. Álvarez-Ortí ${ }^{\mathrm{a}}$, A. Pardo-Giménez ${ }^{\mathrm{b}}$, R. Gómez ${ }^{\mathrm{a}}$, A. Rabadán ${ }^{\mathrm{a}}$ and J.E. Pardo ${ }^{\mathrm{a}, \bowtie}$ \\ ${ }^{a}$ Escuela Técnica Superior de Ingenieros Agrónomos y de Montes, Universidad de Castilla-La Mancha. \\ Campus Universitario s/n, 02071 Albacete, Spain. \\ ${ }^{b}$ Centro de Investigación, Experimentación y Servicios del Champiñón. C/ Peñicas s/n, Apdo. \\ 63, 16220 Quintanar del Rey, Cuenca, Spain. \\ ${ }^{\circledR}$ Corresponding author: jose.pgonzalez@uclm.es
}

Submitted: 07 September 2015; Accepted: 04 April 2016

SUMMARY: In this paper the extraction methods of virgin almond oil and its chemical composition are reviewed. The most common methods for obtaining oil are solvent extraction, extraction with supercritical fluids $\left(\mathrm{CO}_{2}\right)$ and pressure systems (hydraulic and screw presses). The best industrial performance, but also the worst oil quality is achieved by using solvents. Oils obtained by this method cannot be considered virgin oils as they are obtained by chemical treatments. Supercritical fluid extraction results in higher quality oils but at a very high price. Extraction by pressing becomes the best option to achieve high quality oils at an affordable price. With regards chemical composition, almond oil is characterized by its low content in saturated fatty acids and the predominance of monounsaturated, especially oleic acid. Furthermore, almond oil contains antioxidants and fat-soluble bioactive compounds that make it an oil with interesting nutritional and cosmetic properties.

KEYWORDS: Almond; Chemical composition; Extraction; Oil; Quality

RESUMEN: Aceite de almendra virgen: Métodos de extracción y composición. En este trabajo se revisan los métodos de extracción del aceite de almendra virgen y su composición química. Los métodos más habituales para la obtención del aceite son la extracción con disolventes, la extracción con fluidos supercríticos $\left(\mathrm{CO}_{2}\right)$ y los sistemas de presión (prensas hidráulica y de tornillo). El mayor rendimiento industrial, pero también la peor calidad de los aceites, se consigue mediante el uso de disolventes. Además, los aceites obtenidos por este método no se pueden considerar vírgenes, pues se obtienen por medio de tratamientos químicos. La extracción con fluidos supercríticos da lugar a aceites de mayor calidad pero a un precio muy elevado. La extracción mediante prensado se convierte en la mejor opción de extracción, al conseguir aceites de alta calidad a un precio asequible. En cuanto a su composición química, el aceite de almendra se caracteriza por su bajo contenido en ácidos grasos saturados y el predominio de los monoinsaturados, en especial en ácido oleico. Además, el aceite de almendra contiene compuestos bioactivos liposolubles y antioxidantes que lo convierten en un aceite con interesantes propiedades nutricionales y cosméticas.

PALABRAS CLAVE: Aceite; Almendra; Calidad; Composición química; Extracción

Citation/Cómo citar este artículo: Roncero JM, Álvarez-Ortí M, Pardo-Giménez A, Gómez R, Rabadán A, Pardo JE. 2016. Virgin almond oil: Extraction methods and composition. Grasas Aceites, 67 (3): e143. doi: http://dx.doi. org/10.3989/gya.0993152.

Copyright: (C) 2016 CSIC. This is an open-access article distributed under the terms of the Creative Commons Attribution-Non Commercial (by-nc) Spain 3.0 Licence. 


\section{EDIBLE FATS AND VEGETABLE OILS}

The Codex Alimentarius defines edible fats and oils as foodstuffs composed of glycerides of fatty acids. They are of vegetable, animal or marine origin. They may contain small amounts of other lipids such asphosphatides, unsaponifiable constituents and free fatty acids naturally present in the fat or oil (CODEX STAN, 1981).

Fats from a vegetable origin show a predominance of unsaturated fatty acids, which make them liquefy at $25{ }^{\circ} \mathrm{C}$ and are specifically called oils. They are generally rich in oleic and linoleic acid, and saturated fatty acids are reduced to less than $20 \%$. On the other hand, fats with around $30-80 \%$ saturated fatty acids, are solid, and are animal fats, although some of them have a vegetable origin like the ones from cacao bean or palm kernel (Primo, 1997).

The term lipid is more extensive, and comprises all substances that can be extracted with ether or other non-polar solvents like hexane (Primo, 1997).

Each kind of fat has a constant fatty acid composition between determined limits (Larrañaga et al., 1999). The main classes of fatty acids are saturated, monounsaturated and polyunsaturated. Saturated (butirric acid, caprilic acid, palmitic acid, etc.) and monounsaturated (oleic acid) fatty acids can be synthesized in the human body, however, the two more simple polyunsaturated fatty acids (PUFAs), linoleic and $\alpha$-linolenic acids, are synthesized only in plants. These acids are absolutely necessary for life and human health and must be ingested in the diet. Thus, they are called essential fatty acids (Gurr and Harwood, 1991).

Oils from seeds and fruits can be divided among those with a predominant presence of monounsaturated fatty acids, as is the case of oleic acid (olive, rapeseed, palm, etc.), and those with a predominance of linoleic acid (sunflower, hemp, soybean, peanut, maize, etc.).

The main characteristics of the best-known edible vegetable oils have been extensively reported (Cheftel and Cheftel, 1992; Fennema, 1993; Primo, 1997; Lawson, 1999; Graciano, 2006; Rubio et al., 2009; Pardo et al., 2009; Pardo et al., 2011; Pardo et al., 2013).

With regards to almond oil, in spite of its present low global production, it should also be taken into account because it has special physicochemical, sensory and nutritional/therapeutic characteristics that make it a gourmet product with high market potential in the short, medium and long-term. Its extraction and characterization will be the main aim of this review.

\section{ALMOND: A NUT WITH HIGH COMERCIAL AND NUTRITIONAL VALUE}

The almond is the most important nut in the world in terms of commercial production. Almond production is located in Mediterranean climate zones, in the countries of the Mediterranean basin, in California and northwest Mexico, in a small part of Australia and in other reduced areas around the world (FAO, 2015). The production of shell almonds in Spain in 2012 reached $212.063 \mathrm{t}$, with a value of 190,3 million Euros (MAGRAMA, 2014).

Taxonomically, the almond tree, Prunus dulcis, belongs to the Amygdalus subgenus inside the Prunus genus, the Rosaceae family and the order Rosales (Felipe, 2000). Its cultivars are classified depending on the hardness of the shell. Soft and medium-hard shell cultivars show low resistance to attacks by pests, low resistance to rancidity but high shelling percentage (55\% and 35-40\%, respectivelly) (Salazar and Melgarejo, 2002), notably Non Pareil and Guara, respectively. Hard shell varieties present the lowest kernel shelling percentage $(<25 \%)$, but they are better at conserving the organoleptic and commercial characteristics. The main cultivars are Marcona and Desmayo Largueta.

From the botanic point of view, the almond tree nut is a drupe, formed by the evolution of the ovary walls, developing into the pericarp, formed by a pulpy and very fibrous exterior part which can be divided into the exocarp (thin and pubescent) and the mesocarp (thickest), and a lignified interior part that creates a heavy to less heavy coat, the endocarp. At maturity, the pulpy mesocarp dries and opens by its ventral suture, releasing the lignified endocarp (shell). The seed (edible kernel) appears inside the endocarp and ensures the sexual propagation of the species constituting also the commercial part of the nut. The seed contains the embryo coated by the teguments (Felipe, 2000).

The main components that can be found in almond seeds are: lipid fraction (aim of this review), protein fraction, soluble sugars, mineral fraction, and fibrous fraction. A group of compounds called phytochemicals should also be added. They appear in low quantities but have a major influence on almond quality. The proportion of this compound changes according to the cultivar and the kind of cultivation (Prats, 2000; Sathe et al., 2008; Yada et al., 2011; Kodad et al., 2014).

Diets complemented with almond involve a reduction in saturated fatty and trans fatty acid ingestion and an increment in the consumption of linoleic and oleic acid, while not leading to weight gain (JaceldoSiegl et al., 2004; Chen et al., 2006). Its consumption has beneficial effects on human health, and is specially related to the lipid profile in the blood and the risk of cardiovascular diseases (Chen et al., 2006; Jenkins 
et al., 2006), although it also benefits the intestinal transit, reduces blood pressure, prevents anemia and cancer, protects against free radicals, etc (Spiller et al., 1998; Kodad et al., 2011). On the negative side, the potential allergic reaction of susceptible individuals to some protein compounds can present a risk associated with almond consumption (Chen et al., 2006).

\section{ALMOND OIL OBTAINING PROCESS}

The almond oil obtaining process is very similar to the processes for obtaining other nut oils. The nut is harvested before the autumn rains start (August-September). After harvesting, the next step is de-hulling, consisting of the removal of the mesocarp that appears adhered to the nut and has not been lost by falling from the tree. After de-hulling, the nuts are normally exposed to the sun for two or three days (drying), as a general rule, or they are subjected to hot air ventilation, with the aim of finishing their drying. By using drying, the humidity content is considerably reduced by up to $5-8 \%$. After that, cracking takes place, which consists of the separation of the shell and the seed (Harris, 2013). Finally, oil extraction takes place, generating also a solid edible by-product. Some extraction systems will require a previous grinding of the seeds.

The most important operations in almond oil extraction, which would need to be optimized with the aim of obtaining a better quality final product, are drying and extraction.

\subsection{Almond drying}

Fast almond drying is a fundamental operation from the commercial point of view (deficient drying reduces the operational profitability, and the shelf life of nuts susceptible to rancidity) and sanitary point of view (adequate drying prevents the growth and spread of imperfect fungus Aspergillus flavus, and therefore the aflatoxin production and accumulation). Almond drying can be done in different ways: direct sun exposure, hot air oven, using a fan, in a hot air dryer, etc (Piscopo et al., 2011).

\subsection{Almond oil extraction}

Different extraction methods can be used for almond oil extraction, although, as with other seeds, solvent extraction will provide the highest industrial yield (Guerra and Zúñiga, 2003). Traditional equipment uses high temperatures and chemical products, reducing the quality of the oil due to the appearance of undesirable flavors and the inactivation of vitamins and active substances that appear in the raw material (Sineiro et al., 1995), forcing the posterior necessity of refining the oils, so they could not be defined as virgin oils. Matos and Acuña (2010) evaluated three main influence parameters: extraction temperature, size of almond particle and solid/ solvent proportion regarding yield, and defined the optimal conditions as, $90{ }^{\circ} \mathrm{C}, 0.5 \mathrm{~mm}$ and $1: 3$ proportion, respectively, reaching an oil yield of $44.5 \%$. This yield can be improved if samples are irradiated with ultrasounds of $42 \mathrm{kHz}$ (Sharma and Gupta, 2006); observed data using electron microscopy indicate that ultrasound facilitates the development of micro-fractures and the cell walls rupture. It is likely that this effect was also associated with a reduction in particle size. The process consists of aggregating adequate quantities of ammonium sulphate and $t$-butanol to the vegetal material. The protein precipitates as an inter-phase between the superior organic layer and the aqueous layer underneath. The separation of proteins is simultaneously accompanied by oil liberation in the t-butanol phase (Sharma and Gupta, 2004).

In recent years, supercritical fluid extraction $\left(\mathrm{CO}_{2}\right)$ has improved its conception as a viable alternative to conventional solvent extraction methods (Mendiola et al., 2007); the use of lower temperatures and pressures results in higher quality products (Marzouki et al., 2008). Femenia et al. (2001), using pressures of $330 \mathrm{bar}$ and temperatures of $50^{\circ} \mathrm{C}$, extracted the oil contained in raw almonds, raw peeled almonds, and roasted almonds, obtaining oil percentages of $15-16 \%, 27-33 \%$ y $49-64 \%$, respectively. Leo et al. (2005) also extracted almond oil using this system, but using pressures of 350 to $550 \mathrm{bar}$, temperatures of 35 to $50{ }^{\circ} \mathrm{C}$ and solvent rates of 10 to $30 \mathrm{~kg} \cdot \mathrm{h}^{-1}$, and observed that the increase in extraction pressure, and temperature caused an increase in oil yield. It was also observed that, to equal flow and pressure rate, the temperature increase caused an increase in yield of almost four times higher. An explanation to this phenomenon is that it produced an increase in oil solubility in $\mathrm{CO}_{2}$. Experimental results were used to deduct that oil production, the initial stage of extraction, increased with an increase in the $\mathrm{CO}_{2}$ flow rate of 10 to $30 \mathrm{~kg} \cdot \mathrm{h}^{-1}$, with constant pressure and temperature. Thus, oil production increased with the increments in pressure, temperature and flow rate. Later on, Ma et al. (2007) studied the factors that influence the bitter almond oil extraction, finding optimal extraction conditions: extraction pressure $=35 \mathrm{MPa}$, extraction temperature $=50^{\circ} \mathrm{C}$, $\mathrm{CO}_{2}$ flow rate $=24 \mathrm{l} / \mathrm{h}$, almond particle size $=0.6 \mathrm{~mm}$ and extraction time $=2 \mathrm{~h}$. The factor sequence that affects extraction is: almond particle size $>$ extraction time $>$ extraction pressure $>\mathrm{CO}_{2}$ flow rate $>$ extraction temperature. Under these conditions, almond oil yield reaches $53 \%$.

An alternative to solvent use is the use of pressing, with both hydraulic and screw presses. 
As a general rule, the hydraulic press offers lower profitability due to the high demand of labor force; although the obtained oils would possibly find an increased acceptance by consumers because the oils maintain their physico-chemical and sensorial properties better (Da et al., 2014; Sena-Moreno et al., 2015). Extraction using a screw press demands a previous thermal conditioning of the material, resulting in a decrease in the quality of the final product (Rohne, 1971). By comparing the almond oils extracted using hydraulic press with the ones extracted using solvents, several authors found that the first ones had a higher tendency toward auto-oxidation (Dugo et al., 1979; Salvo et al., 1980). Prats (2000), obtained yields of $40-45 \%$, using sweet almonds and the hydraulic press. The oil obtained using this method was quite fluid and had a pleasing and light, sweet flavor, and were more stable than others to oxidation processes, which is not in agreement with the findings of Dugo et al. (1979) and Salvo et al. (1980).

Regarding the screw press, although it is generally defined as a cold pressing system, it requires a temperature increase (preheating) to obtain better results. This increase produces a better oil separation, which can affect extraction yield. In some screw presses, temperature is hard to control and, therefore, the yield presents higher variations (Álvarez-Ortí et al., 2012). Recently Martínez et al. (2013), evaluated the combined effects of almond humidity $(4,6,8,10$ y $12 \%)$ and preheating press temperature $(20,40 \mathrm{y}$ $60{ }^{\circ} \mathrm{C}$ ) on the yield and the quality of obtained oils, and observed that the largest quantity of oil $(79,3 \%)$ was obtained with a seed humidity of $8 \%$ and a preheating temperature of $40{ }^{\circ} \mathrm{C}$. The increase in humidity from 4 to $8 \%$ resulted in a higher yield but a posterior increase from 8 to $12 \%$, caused a light decrease. All extraction conditions used were compatible with an acceptable physicochemical quality.

Almond oil extraction using supercritical fluids $\left(\mathrm{CO}_{2}\right)$ and pressing (both hydraulic and screw press) provides a product that is fit for human consumption with the pleasant sensorial characteristics that belong the initial product (the almond), consequently no refining is needed, making the product a virgin oil.

\section{CHEMICAL COMPOSITION OF ALMOND OIL}

Most research about almond composition has focused on lipid fraction and fatty acids. A high variability in oil content has been proved (Table 1). The percentage of variation ranges from $30.1 \%$, found in Portuguese samples (Martins et al., 2000) and the $62.9 \%$ in Iranian samples (Imani et al., 2012).

Conducted studies indicate that lipid content depends mainly on the cultivar (genotype), but other factors such as the edaphic and climatic conditions have been found (García et al., 1996; Sathe, 1993; Yada et al., 2013; Kodad et al., 2014).
TABLE 1. Oil content of samples (\%) depending on their origin

\begin{tabular}{lrll}
\hline Oil content (\%) & Genotype & Origin & \multicolumn{1}{c}{ Reference } \\
\hline $53.1-61.7$ & 19 & Spain & García et al., 1996 \\
$53.6-56.1$ & 5 & USA & Sathe, 1993 \\
$36.0-53.0$ & 21 & USA & Abdallah et al., 1998 \\
$30.1-51.0$ & 12 & Portugal & Martins et al., 2000 \\
$39.6-62.9$ & 18 & Iran & Imani et al., 2012 \\
$48.0-57.5$ & 9 & Argentine & Maestri et al., 2015 \\
\hline
\end{tabular}

\subsection{Fatty acids}

In the almond lipid fraction five fatty acids are predominant: oleic acid (C18:1), linoleic acid (C18:2), palmitic acid (C16:0), palmitoleic acid (C16:1) and stearic acid (C18:0). These fatty acids appear in descending order of composition and constitute $95 \%$ of the total (Table 2). This fraction is complemented by eight less common fatty acids (Saura et al., 1988; García et al., 1996; Abdallah et al., 1998). Regarding the most abundant fatty acids, the unsaturated fatty acids represent about $90 \%$ of the fatty acid content. Regarding the unsaturated fatty acids, monounsaturated represents the highest proportion with respect to polyunsaturated (Saura et al., 1988; Abdallah et al., 1998; Kodad, 2006).

The greatest variability in fatty acid contenta has been observed by comparing different genotypes. Palmitoleic and stearic acids show greater variability (coefficient of variation of more than $10 \%$ ), followed by linoleic and palmitic acids (coefficients of variation of more than $4 \%$ and $7 \%$, respectively) and, finally, the oleic acid, with a coefficient of variation smaller than 2\% (Kodad, 2006). Yada et al. (2013), also discovered significant cultivar differences by comparing saturated fatty acids (values ranged from 3.2 to $4.7 \mathrm{~g} \cdot 100 \mathrm{~g} \mathrm{~g}^{-1}$ fresh almond) and the polyunsaturated fatty acids (values ranged from 9.4 to 15.1 $\mathrm{g} \cdot 100 \mathrm{~g}^{-1}$ fresh almond). Comparing harvests (in two consecutive years), highest variability was found in palmitoleic and stearic acids (more than 10\%); while oleic acid showed low coefficients of variation, with contents ranging from $63.1 \%$ to $78.7 \%$ of the fatty acid content. Linoleic acid values ranged from 12 to $27 \%$ of the fatty acid content (Kodad, 2006). Kodad et al. (2014), found that for traditional Spanish cultivars, the effect of genotype, year and genotype $\mathrm{x}$ year interaction, was significant in relation to variability in the contents of stearic, palmitoleic, linoleic and oleic acids. However, apart from palmitoleic acid, the magnitude of difference was insignificant in comparison with the variability among genotypes.

García et al. (1996), discovered that the lowest value for oleic acid was found in Californian cultivar 
TABLE 2. Fatty acid composition (\%) of almond oil

\begin{tabular}{ccccc}
\hline $\begin{array}{c}\text { Palmitic } \\
\text { acid } \\
\text { C16:0 }\end{array}$ & $\begin{array}{c}\text { Palmitoleic } \\
\text { acid } \\
\text { C16:1 }\end{array}$ & $\begin{array}{c}\text { Stearic } \\
\text { acid } \\
\text { C18:0 }\end{array}$ & $\begin{array}{c}\text { Oleic } \\
\text { acid } \\
\text { C18:1 }\end{array}$ & $\begin{array}{c}\text { Linoleic } \\
\text { acid } \\
\text { C18:2 }\end{array}$ \\
\hline $5.2-6.7$ & $0.3-0.6$ & $0.2-1.7$ & $57.5-78.7$ & $12.0-33.9$ \\
\hline
\end{tabular}

Texas $(57.5 \%)$ and the highest in the Spanish cultivar Ramillete (74.2\%). Regarding linoleic acid, the opposite was observed. A possible explanation for the presence of the highest oleic acid concentrations in European cultivars, compared to the American ones, is the positive correlation observed between the shell thickness and the oleic acid with $\mathrm{r}=0.44$, which matches the lower oleic acid content in the American cultivars than in the ones from the Mediterranean basin (Askin et al., 2007). Nevertheless, the most important part of García et al. (1996) research was the statistical analysis used to classify almond tree cultivars form different origins, based on their similarities in the fatty acid profile. This research was completed by incorporating classification criteria, minority fatty acid concentrations (Martín et al., 1998) and triglyceride compositions (Martín et al., 1999).

Sathe et al. (2008), analyzing Californian cultivars, found that palmitic, oleic and linoleic fatty acids were predominant in the lipid composition regardless of the cultivar, crop origin and harvest year. The ranges of these fatty acids were from $5.15 \%$ to $6.65 \%$, from $59.52 \%$ to $73.80 \%$, and from $19.49 \%$ to $33.29 \%$, respectively; mean values for oleic and linoleic acids were $65.77 \%$ and $27.18 \%$. Palmitoleic acid varied from $0.31 \%$ to $0.57 \%$, stearic acid from $0.24 \%$ to $1.66 \%, \alpha$-linolenic acid from $0.05 \%$ to $0.09 \%$, and the araquidic acid from $0.03 \%$ to $0.07 \%$. All these acids showed presence in all the studied samples. Similar values for the three main fatty acids were previously found in Iranian almonds. $75.4 \%$ of the total fatty acid content was oleic acid, 19.4\% was linoleic acid and 5.3\% palmitic acid (Safari and Alizadeh, 2007).

Another important aspect is the existing relationship among the different fatty acids. The most frequently studied relationship is the oleic/linoleic ratio because of its nutritional importance, which shows a wide range of variation depending on the considered author; from 1.96 to 3.05 (Saura et al., 1988), from 2.35 to 6.56 (Kodad, 2006) or from 1.8 to 3.8 (Sathe et al., 2008). The correlation observed in both fatty acids is very high and negative, with r values from -0.92 (Askin et al., 2007) to -0.99 (Sathe et al., 2008).

\subsection{Triglycerides}

In ripe almonds, fatty acids appear mainly in the form of triglycerides (Nassar et al., 1977). In fact, almond oil is the conventional nut oil with the highest content in triglycerides, about 98\% (Miraliakbari and Shahidi, 2008), which results in a low acidity index (Saura et al., 1988). However, its composition has not been the issue of many research works.

The kind and quantity of oil triglycerides determine the final physical and functional properties of them (Jahaniaval et al., 2000). Prats (2000) detected nine triglycerides in ten studied cultivars from seven different production zones, observing this order, from high to low contents:

$\mathrm{OOO}>\mathrm{OLO}>\mathrm{OLL}>\mathrm{POO}>\mathrm{PLO}>$ $\mathrm{SOO} \cong \mathrm{LLL} \cong \mathrm{PLL}>\mathrm{PLP}$

where $\mathrm{O}$ represents oleic acid, L linoleic acid, $\mathrm{P}$ palmitic acid and $\mathrm{S}$ stearic acid.

The first five are predominant triglycerides and the last four are less common. Due to the fact that oleic acid is the most abundant fatty acid, triglycerides containing this fatty acid are also more common. OOO have the highest content with values around 11.3 to $31.3 \mathrm{mg} \cdot 100 \mathrm{~g}^{-1}$ of dry sample, and the content in OLO varies from 15.7 to $6.9 \mathrm{mg} \cdot 100 \mathrm{~g}^{-1}$ of dry sample. Hereafter OLL and POO triglycerides appear. The PLP triglyceride is the one that appears in the smallest quantities. The OOO triglyceride has the highest correlation with the rest of triglycerides and moreover it has a negative sign, except for POO and SOO, which makes sense because they appear in the largest proportions in almond oil.

With a similar approach, Martín (1999) conducted a previous study on 19 representative cultivars from the main almond production zones in the world, finding the same triglycerides in the same concentration order. Triglycerides OOO and OLO together amount to $60 \%$ of the triglyceride total. The main aim of this research was the use of the concentration data of different triglycerides to determine the cultivar oil origin with the two-fold purpose of characterizing the product to avoid industrial frauds and to assign genotypes into groups with homogeneous behavior concerning cultivar selection. In general, triglyceride composition in almond oil was very similar in the different cultivars.

Holcapek et al. (2003) found 18 triglycerides in almond oil, probably due to the better resolution in the analysis carried out with the proposed working method. Nevertheless, the triglyceride order by content has not been the same as in other revised research: OLO (28.0\%), OLL (27.6\%), OOO (13.3\%), LOP (11.3\%) LLL (8.7\%), LLP $(4.8 \%)$, OOP $(2.7 \%)$, SLO $(1.8 \%)$, SOO $(0.6 \%)$, PLP $(0.5 \%)$, OOMo $(0.5 \%)$, OLLn (0.1\%), LLMo (0.1\%), OLMo $(0.1 \%)$, GLO $(0.1 \%)$, POP $(0.1 \%)$, OOMa $(0.05 \%)$ and GOO $(0.05 \%)$, where Mo is heptadecanoic acid, $\mathrm{Ln}$ is linolenic acid, Ma is margaric acid and $\mathrm{G}$ is gadoleic acid.

Cherif et al. (2004), found 10 triglycerides with LOO that had not been identified by other authors before. They did not, however, find PLL in an interesting research about the fatty acid evolution and 
triglycerides throughout the development and ripeness of the almond seed. They conclude that differences in the triglyceride profile can be useful to distinguish cultivars. However, the triglyceride composition found in almond oil was similar for all the studied cultivars. Triglyceride total contents for major components (OOO, LOO, LLO, LOP y POO) were very similar in the three studied varieties, and the OOO and LOO added $60-70 \%$ of the total of triglycerides, which is in accordance with Martín (1999). Triglyceride differences suggest that $\mathrm{OOO}$ triglyceride can be used to discriminate among cultivars, for example, to detect adulterations in almond oil.

Later, by using a reverse non aqueous HPLC method with an acetonitrile -2-propanol gradient, Holcapek et al. (2005), identified unequivocally the highest number of triglycerides ever reported in analyzed oils. This allowed them to detect 24 triglycerides in almond oil. The obtained values are in line with those obtained in the consulted literature.

Barreira et al. (2012), made a study about almonds that had been collected over three months in Trás-os-Montes (Portugal), with the aim of discovering differences between the Protected Designation of Origin (DOP) Amêndoa Douro and the nonDOP commercial cultivars. The comparative test provided general conclusions for almost all the evaluated cases. The DOP Amêndoa Douro cultivars had the highest content in OLL and LLP triglycerides. But apart from previous considerations, results confirmed the prevalence of OOO and OLO triglycerides. In general, detected profiles were similar to previous research (Martín, 1999; Prats, 2000).

Recent studies carried out using wild almonds in Iran, have resulted in the triglyceride composition: OOO $(47,27 \%), \mathrm{POO}+\mathrm{SOL}(26,25 \%), \mathrm{OOL}+$ PLnP $(10,67 \%)$. The triglyceride profile found was very similar to the olive oil profile (Givianrad et al., 2013).

The advantage of using a triglyceride analysis, in comparison to the fatty acid profile, is that a stereospecific distribution of fatty acids in the glycerol molecule is genetically controlled and, as a result, the information content of intact triglycerides is generally higher (Aparicio and Aparicio-Ruiz, 2000; Bail et al., 2009).

\subsection{Liposoluble bioactive compounds}

Pasini et al. (2013), established a lipid classification, in which unsaponifiable fraction and complex lipids (phospholipids and glycolipids) appear. These fractions are quantitatively small but with huge importance from the biological and nutritional point of view. The almond composition in these compounds, denominated fat-soluble bioactives, consists of tocopherols, tocotrienols, phospholipids, sterols, phytosterols, phytostanols, sphingolipids, squalene and terpenoids. This group of compounds has been included by several authors inside the phytochemical concept (Alasalvar and Pelvan, 2011).

The unsaponifiable fraction is basically formed by sterols, methylsterols, aliphatic alcohols, and fat-soluble vitamins (Prats, 2000). More representative sterols are sitosterol $(80-86 \%)$, campesterol $(2-4 \%)$ and traces of stigmasterol (Garcia et al., 1978). Generic studies about nuts have reported an unsaponifiable substance content of $0.44 \mathrm{~g} \cdot 100 \mathrm{~g}^{-1}$ of extracted oil, with a range from 0.35 to 0.53 (Kornsteiner et al., 2006).

\section{CHEMICAL COMPOSITION OF DEFATTED FLOUR OR ALMOND CAKE}

Almond flour or cake is the secondary product obtained from the extraction of oil contained in the almond (Sarkis et al., 2014). This flour has high nutritional value, due to its high protein content; consequently, it can be used for human or animal feeding, especially ruminants and fish. These flours are also rich in fiber and energy and offer potential benefits when they are used in the development of bioprocesses in the production of chemical organic products and bio-molecules. It can also be used in the production of enzymes, antibiotics, bio-pesticides, vitamins and other biochemical products. Research in industrial enzyme production has shown promising results. A substrate mix for fermentation has shown advantages in this kind of application. These flours have also been used in the elaboration of soups, pastries, sauces, etc. An interesting alternative to these uses would be their utilization as a nutritional supplement in the specific substrates used in mushroom and edible fungi cultivation, in the same way the flour generated in grape seed oil production has been used (Pardo-Giménez et al., 2012).

Sarkis et al. (2014) analyzed the water soluble compounds of flour from almonds and other nuts after oil extraction using a screw press. Although tocopherols and part of the phospholipids concentrate in the oil, a high phenolic content remains in the flour. Therefore, flours have a huge potential as secondary products suitable and economically viable for the recovery of phenolic compounds (Matthaus, 2002). Taking into account the antioxidant activity of some flours and their extracts, they could be used as functional ingredients, aggregated to improve foods or as natural antioxidants for products that contain oil and fat. Their flavonol content was $5.1 \mathrm{mg} \cdot 100 \mathrm{~g}^{-1}$ of dry matter (Sarkis et al., 2014).

Physicochemical, bioactive and antimicrobial properties have also been analyzed after the cold pressing and separation of different edible oils, which included almond oil (Karaman et al., 2015). The oil content, protein and raw fiber of almond flour was $8.8 \%, 49 \%$ and $5.9 \%$, respectively. Consequently, it 
can be used to enrich the protein content of different food products. Residual oil content was shown to be significant regarding stability in storage, its functionality and the nutritional characteristics of by-products. The $\mathrm{pH}$ value and water activity value were 6.14 and 0.486 , respectively, with a dry matter content of $92.41 \%$.

Flours are also rich in minerals (ash content of $5.72 \%$ ), especially in macro-elements such as potassium $\left(1473.4 \mathrm{mg} \cdot 100 \mathrm{~g}^{-1}\right)$, calcium $\left(895.8 \mathrm{mg} \cdot 100 \mathrm{~g}^{-1}\right)$, magnesium $\left(536.1 \mathrm{mg} \cdot 100 \mathrm{~g}^{-1}\right)$ and phosphorous $(522.3$ $\left.\mathrm{mg} \cdot 100 \mathrm{~g}^{-1}\right)$. An interesting content of phenolic compounds was also found: gallocatechin (1321.5 ppm), epigallocatechin (77.96 ppm), quercetin (54.71 ppm), gallic acid (49.79 ppm), p-coumaric acid (47.13 $\mathrm{ppm})$, resveratrol (16.42 ppm), quercetin hydrate (14.24 ppm), catechin (14.17 ppm), etc. (Karaman et al., 2015). Almond cake extracts showed antibacterial activity depending on their concentration. Almond flour did not show any antibacterial activity concerning the tested microorganisms, except for Listeria monocytogenes in the lowest concentration.

\section{CONCLUSIONS}

In summary, fresh almond oil, extracted using supercritical fluids $\left(\mathrm{CO}_{2}\right)$ or by pressing, shows low contents in free fatty acids, peroxides and phosphatides, and therefore it can be consumed directly, without refining, as a $100 \%$ virgin product. The rising global production of almonds, together with the demand for new oil specialties, make it necessary to research appropriate methods for improving almond oil production. Its quantitative and qualitative extraction is essential to determine the feasibility of transforming it into a commercial produc (Martínez et al., 2013).

\section{REFERENCES}

Abdallah A, Ahumada MH, Gradziel TM. 1998. Oil content and fatty acid composition of almond kernels from different genotypes and California production regions. J. Am. Soc. Hortic. Sc. 123, 1029-1033.

Alasalvar C, Pelvan E. 2011. Fat-soluble bioactives in nuts. Eur. J. Lipid Sci. Technol. 113, 943-949. http://dx.doi. org/10.1002/ejlt.201100066

Álvarez-Ortí M, Quintanilla C, Sena E, Alvarruiz A, Pardo J.E. 2012. The effects of a pressure extraction system on the quality parameters of different virgin pistachio (Pistacia vera L. var. Larnaka) oils. Grasas Aceites, 63, 260-266. http://dx.doi.org/10.3989/gya.117511

Aparicio R, Aparicio-Ruiz R. 2000. Authentication of vegetable oils by chromatographic techniques. J. Chromatogr. 88, 93-104. http://dx.doi.org/10.1016/S0021-9673(00)00355-1

Askin M, Baltab M, Tekintasc F, Kazankayab A, Balta F. 2007. Fatty acid composition affected by kernel weight in almond (Prunus dulcis Mill.) genetic resources. J. Food Compos. Anal. 20, 7-12. http://dx.doi.org/10.1016/j.jfca.2006.06.005

Bail S, Stuebiger S, Unterweger H, Buchbauer G, Krist S. 2009. Characterization of volatile compounds and triacylglycerol profiles of nut oils using SPME-GC-MS and MALDITOF-MS. Eur. J. Lipid Sci. Technol. 111, 170-182. http:// dx.doi.org/10.1002/ejlt.200800007
Barreira J, Casal S, Ferreira I, Peres AM, Pereira JBO. 2012. Supervised chemical pattern recognition in almond (Prunus dulcis) portuguese PDO cultivars: PCA- and LDA-based triennial study. J. Agric. Food Chem. 60, 9697-9704. http:// dx.doi.org/10.1021/jf301402t

Cheftel J, Cheftel H. 1992. Introducción a la bioquímica y tecnología de los alimentos, Vol. I., Ed. Acribia, S.A., Zaragoza.

Chen CY, Lapsley K, Blumberg J. 2006. A nutrition and health perspective on almond. J. Sci. Food Agric. 86, 2245-2250. http://dx.doi.org/10.1002/jsfa.2659

Cherif A, Sebei K, Boukhchina S, Kallel H, Belkacemi K, Arul J. 2004. Kernel fatty acid and triacylglycerol composition for three almond cultivars during maturation. J. Am. Oil Chem. Soc. 81, 901-905.

Da C, Hongzhi L, Li L, Hui H, Qiang W. 2014. Quality comparison of almond oil extracted with different processes and correlation analysis of quality indexes. J. Chinese Cereals Oils Assoc. 2, 47-52.

Dugo G, D'alcontre I, Cotroneo A, Salvo F. 1979. Composizione dell'olio di mandorle. NotaI: acidi grassi, idrocarburi esteroli di alcune varietà di mandorle dolci siciliane. Riv. Ital. Sostanze Gr. 56, 201-203.

FAO. 2015. Food and Agriculture Organization of the United Nations. http://faostat3.fao.org/browse/Q/QC/E.

Felipe A. 2000. El almendro. El material vegetal. Ed. Mira Editores. Zaragoza.

Femenia A, Garcia M, Simal S, Rossello C, Blasco M. 2001. Effects of supercritical carbon dioxide (SC-CO2) oil extraction on the cell wall composition of almond fruits. J. Agric. Food Chem. 49, 5828-5834. http://dx.doi.org/10.1021/ jf010532e

Fennema OR. 1993. Química de los Alimentos, Ed. Acribia, S.A. Zaragoza.

García C, Grané N, Berenguer V, García JE, Martín ML. 1996. Major fatty acid composition of 19 almond cultivars of different origins. A chemometric approach. J. Agric. Food Chem. 46, 963-967. http://dx.doi. org/10.1021/jf950505m

García R, Carballido A, Díaz A. 1978. Contribución al estudio de los aceites de frutos secos españoles. Composición de insaponificable. 1. Fracción de esteroles. Anales de Bromatología, 30, 63-89.

Givianrad M, Saber-Tehrani M, Jafari JA. 2013. Chemical composition of oils from wild almond (Prunus scoparia) and wild pistachio (Pistacia atlantica). Grasas Aceites, 64, 77-84. http://dx.doi.org/10.3989/gya.070312

Graciano E. 2006. Los aceites y grasas: Composición y propiedades. Ed. AMV Ediciones \& Mundi-Prensa, Madrid.

Guerra E, Zúñiga M. 2003. Tratamiento enzimático en la extracción de aceite de pipa de uva, Vitis vinifera, por prensado en frío. Grasas Aceites, 54, 53-57. http://dx.doi.org/10.3989/ gya.2003.v54.i1.277

Gurr MI, Harwood JL. 1991. Lipid Biochemistry: An Introduction. Ed. Chapman \& Hall, London.

Harris LJ. 2013. Improving the Safety and Quality of Nuts. Ed. Woodhead Publishing Limited, Cambridge.

Holčapek M, Jandera P, Zderadička P, Hrubá L. 2003. Characterization of triacylglycerol and diacylglycerol composition of plant oils using high-performance liquid chromatography-atmospheric pressure chemical ionization mass spectrometry. J. Chromatogr. 1010, 195-215. http://dx.doi.org/10.1016/S0021-9673(03)01030-6

Holčapek M, Lisa M, Jandera P, Kabátová N. 2005. Quantitation of triacylglycerols in plant oils using HPLC with APCI-MS, evaporative light-scattering, and UV detection. J. Sep. Sci. 28, 1315-1333. http://dx.doi.org/10.1002/jssc.200500088

Imani A, Hadadi A, Amini H, Vaeizi M, Jolfaei B. 2012. The effect of genotype and year on the average percentage of oil seed content of almond. Int. J. Nuts Related Sci. 3, $37-40$.

Jaceldo-Siegl K, Sabate J, Rajaram S, Fraser G. 2004. Long-term almond supplementation without advice on food replacement induces favorable nutrient modifications to the habitual diets of free-living individuals. Br. J. Nutr. 92, 533-540. http://dx.doi.org/10.1079/BJN20041223 
Jahaniaval F, Kakuda Y, Marcone MF. 2000. Fatty acid and triacylglycerol compositions of seed oils of five Amaranthus accessions and their comparison to other oils. J. Am. Oil Chem. Soc. 77, 847-852. http://dx.doi.org/10.1007/ s11746-000-0135-0

Jenkins DJ, Kendall CW, Josse AR, Salvatore S, Brighenti F, Augustin LS. 2006. Almonds decrease postprandial glycemia, insulinemia, and oxidative damage in healthy individuals. J. Nutr. 136, 2987-2992.

Karaman S, Karasu S, Tornuk F, Toker O, Geçgel U, Sagdic O. 2015. Recovery potential of cold press byproducts obtained from the edible oil industry: Physicochemical, bioactive, and antimicrobial properties. J. Agric. Food Chem. 63, 2305-2313. http://dx.doi.org/10.1021/ jf504390t

Kodad O. 2006. Criterios de selección y de evaluación de nuevas obtenciones autocompatibles en un programa de mejora genética del almendro (Prunus amygdalus Batsch). Tesis doctoral, Universidad de Lleida. Lleida.

Kodad O, Estopañan G, Juan T, Mamouni A, Socias R. 2011. Tocopherol concentration in almond oil: Genetic variation and environmental effects under warm conditions. J. Agric. Food Chem. 59, 6137-6141. http://dx.doi.org/10.1021/ jf200323c

Kodad O, Estopañán G, Juan T, Socias i Company R. 2014. Tocopherol concentration in almond oil from Moroccan seedlings: Geographical origin and post-harvest implications. J. Food Compos. Anal. 33, 161-165. http://dx.doi. org/10.1016/j.jfca.2013.12.010

Kornsteiner MW. 2006. Tocopherols and total phenolics in 10 different nut types. Food Chem. 98, 381-387. http:// dx.doi.org/10.1016/j.foodchem.2005.07.033

CODEX STAN. 1981. Codex Alimentarius, International Food Standards. Standard for Edible Fats and Oils not Covered by Individual Standards.F.A.O. Rome.

Lawson H, 1999. Aceites y grasas alimentarios. Ed. Acribia, S.A., Zaragoza.

Leo L, RescioL, Ciurlia L, Zacheo G. 2005. Supercritical carbon dioxide extraction of oil and $\alpha$-tocopherol from almond seeds. J. Sci. Food Agric. 85, 2167-2174. http://dx.doi. org/10.1002/jsfa.2244

Ma Y, Zhao Z, Li K, Ma X, Guo C, Shi Q. 2007. Optimization of technology for almond oil extraction by supercritical CO2. Transac. Chinese Soc. Agric. Eng. 4, 272-275.

Maestri D, Martínez M, Bodoira R, Rossi Y, Oviedo A, Pierantozzi P. 2015. Variability in almond oil chemical traits from traditional cultivars and native genetic resources from Argentina. Food Chem. 170, 55-61. http:// dx.doi.org/10.1016/j.foodchem.2014.08.073

MAGRAMA. 2014. Anuario de estadística 2013. Ed. Ministerio de Agricultura, Alimentación y Medio Ambiente, Madrid.

Martín ML. 1999. Comparative study on the triglyceride composition of almond kernel oil. A new basis for cultivar chemometric characterization. J. Agric. Food Chem. 47, 3688-3692. http://dx.doi.org/10.1021/jf981220n

Martín ML, García L, Berenguer V, Grané N. 1998. New contribution to the chemometric characterization of almond cultivars on the basis of their fatty acid profiles. J. Agric. Food Chem. 46, 963-967. http://dx.doi.org/10.1021/ jf970672h

Martínez ML, Penci MC, Marin MA, Pablo D, Ribotta PD, Maestri DM. 2013. Screw press extraction of almond (Prunus dulcis (Miller) D.A. Webb): Oil recovery and oxidative stability. J. Food Eng. 119, 40-45. http://dx.doi. org/10.1016/j.jfoodeng.2013.05.010

Martins A, Gomes C, Ferreira L. 2000. Almond production and characteristics in Algarve, Portugal. Nucis 9, 6-9.

Marzouki H, Piras AM, Rosa AD. 2008. Extraction and separation of volatile and fixed oils from berries of Laurus nobilis L. by supercritical CO2. Molecules 13, 1702-1711. http:// dx.doi.org/10.3390/molecules13081702

Matos A, Acuña J. 2010. Influencia del tiempo, tamaño de partícula y proporción sólido-líquido en la extracción de aceite crudo de la almendra de durazno (Prunus persica). Rev. Investig. Ciencia Tecnol. Alimentos 1, 1-6.
Matthaus B. 2002. Antioxidant activity of extracts obtained from residues of different oilseeds. J. Agric. Food Chem. 50, 3444-3452. http://dx.doi.org/10.1021/jf011440s

Mendiola J, Herrero M, Cifuentes A, Ibáñez E. 2007. Use for compressed fluids for sample preparation: Food applications. J. Chromatogr. 1152, 234-246. http://dx.doi. org/10.1016/j.chroma.2007.02.046

Miraliakbari H, Shahidi F. 2008. Antioxidant activity of minor components of tree nut oils. Food Chem. 111, 421-427. http://dx.doi.org/10.1016/j.foodchem.2008.04.008

Nassar AR, El-Tahawi B, El-Deen SA. 1977. Chromatographic identification of oil and amino acid constituents in kernels of some almond varieties. J. Am. Oil Chem. Soc. 34 553-558. http://dx.doi.org/10.1007/BF02909081

Pardo JE, Cuesta MA, Alvarruiz A, Granell JD, ÁlvarezOrtí M. 2011. Evaluation of potencial and real qualities of virgin olive oil from the designation of origin (DO) "Aceite Montes de Alcaraz" (Albacete, Spain). Food Chem. 124, 1684-1690. http://dx.doi.org/10.1016/j. foodchem.2010.07.068

Pardo JE, Fernández E, Rubio M, Alvarruiz A, Alonso G. 2009. Characterization of grape seed oil from different grape varieties (Vitis vinifera). Eur. J. Lipid Sci. Technol. 111, 188-193. http://dx.doi.org/10.1002/ejlt.200800052

Pardo JE, Sena E, Cuesta MA, Granell JD, Valiente J, ÁlvarezOrtí M. 2013. Evaluation of potencial and real quality of virgin olive oil from "Campos de Hellín" (Albacete, Spain). J. Am. Oil Chem. Soc. 90, 851-862. http://dx.doi. org/10.1007/s11746-013-2222-3

Pardo-Giménez A, Zied D, Alvarez-Ortí M, Rubio M, Pardo JE. 2012. Effect of supplementing compost with grape seed meal on Agaricus bisporus production. J. Sci. Food A gric 92, 1665-1671. http://dx doi.org/10.1002/jsfa.5529

Pasini F, Riciputi Y, Verardo V, Caboni MF. 2013. Phospholipids in cereals, nuts and some selected oilseeds. Recent Research Develop. Lipids 9, 139-201

Piscopo A, Romeo FV, Poiana M. 2011. Effect of drying process on almond (Prunus dulcis (Mill.) D.A. Webb) Kernel composition. Riv. Ital. Sostanze Gr. 88, 153-160.

Prats MS. 2000. Caracterización quimiométrica de diez variedades de almendra cultivadas en diferentes localidades. Ed. Universidad de Alicante, Alicante.

Primo E. 1997. Química de los alimentos. Ed. Síntesis, Madrid.

Rohne G. 1971. Extracción del aceite de granilla de uva. Grasas Aceites 22, 393-400.

Rubio M, Álvarez-Ortí M, Alvarruiz A, Fernández E, Pardo JE. 2009. Characterization of oil obtained from grape seeds collected during the berry development. J. Agric. Food Chem. 57, 2812-2815. http://dx.doi.org/10.1021/jf803627t

Safari M, Alizadeh H. 2007. Oil Composition of Iranian Major Nuts. J. Agric. Sci. Technol. 9, 251-256.

Salazar D, Melgarejo P. 2002. El cultivo del almendro. Ed. Mundi-Prensa \& AMV, Madrid.

Salvo F, Dugo G, D'alcontre I, Cotroneo A. 1980. Composizione dell'olio dimandorle. NotaII: differenziazione dell'olio di mandorle dolci da sue miscele con olio di semidipesco e di albicocco. Riv. Ital. Sostanze Gr. 57, 24-26.

Sarkis JR, Correa AP, Michel I, Brandeli ACI, Tessaro IC. 2014. Evaluation of the phenolic content and antioxidant activity of different seed and nut cakes from the edible oil industry. J. Am. Oil Chem. Soc. 91, 1773-1782. http://dx.doi. org/10.1007/s11746-014-2514-2

Sathe SK. 1993. Solubilization, electrophoretic characterization and in vitro digestibility of almond (Prunus amygdalus) proteins. J. Food Biochem. 16, 249-264. http://dx.doi. org/10.1111/j.1745-4514.1992.tb00450.x

Sathe SK, Seeram HH, Kshirsagar D, Lapsley KA. 2008. Fatty acid composition of California grown almonds. J. Food Sci. 73, 607-614. http://dx.doi. org/10.1111/j.1750-3841.2008.00936.x

Saura F, Cañellas J, Soler L. 1988. La almendra. Composición, variedades, desarrollo y maduración. Ed. Instituto Nacional de Investigaciones Agrarias (INIA), Madrid.

Sena-Moreno E, Pardo JE, Catalán L, GómezR, Pardo A, ÁlvarezOrtí M. 2015. Drying temperature and extraction method influence physicochemical and sensory characteristics 
of pistachio oils. Eur. J. Lipid Sci. Technol. 117, 684-691. http://dx.doi.org/10.1002/ejlt.201400366

Sharma A, Gupta MN. 2004. Oil extraction from almond, apricot and rice bran by three-phase partitioning after ultrasonication. Eur. J. Lipid Sci. Technol. 106, 183-186. http:// dx.doi.org/10.1002/ejlt.200300897

Sharma A, Gupta MN. 2006. Ultrasonic pre-irradiation effect upon aqueous enzymatic oil extraction from almond and apricot seeds. Ultrason Sonochem 13, 529-534. http:// dx.doi.org/10.1016/j.ultsonch.2005.09.008

Sineiro J, Domínguez H, Núñez M. 1995. Pepitas de uva como fuente de aceite y proteína. Alimentación, Equipos y Tecnología 4, 49-56.
Spiller GA, Jenkins DA, Bosello O, Gates JE, Cragen L, Bruce B. 1998. Nuts and plasma lipids: an almond-based diet lowers LDL-C while preserving HDL-C. J. Am. Coll Nutr. 17, 285-290. http://dx.doi.org/10.1080/07315724.19 98.10718761

Yada S, Huang G, Lapsley K. 2013. Natural variability in the nutrient composition of California-grown almonds. J. Food Compos. Anal. 30, 80-85. http://dx.doi.org/10.1016/j. jfca.2013.01.008

Yada S, Lapsley P, Huang G. 2011. A review of composition studies of cultivated almonds: Macronutrients and micronutrients. J. Food Compos. Anal. 24, 469-480. http://dx.doi. org/10.1016/j.jfca.2011.01.007. 